Article

\title{
The Methodology of Landscape Quality (LQ) Indicators Analysis Based on Remote Sensing Data: Polish National Parks Case Study
}

\author{
Barbara Sowińska-Świerkosz ${ }^{1}$ (1) and Malwina Michalik-Śnieżek ${ }^{2, *}$ \\ 1 Department of Hydrobiology and Ecosystems Protections, University of Life Sciences in Lublin, \\ Dobrzańskiego 37, 20-262 Lublin, Poland; barbara.sowinska@wp.pl \\ 2 Department of Grassland and Landscape Shaping, University of Life Sciences in Lublin, Akademicka 13, \\ 20-950 Lublin, Poland \\ * Correspondence: malwina.sniezek@up.lublin.pl; Tel.: +48-8144-560-30
}

Received: 17 February 2020; Accepted: 21 March 2020; Published: 2 April 2020

\begin{abstract}
Landscape quality (LQ) encompasses diverse characteristic of the natural and cultural environment. The most effective tool to analyze LQ is the use of indicators. The main problem in the assessment of LQ is not the lack of indicators, but its multitude. That is why, the indicators' categorization is a problematic issue. The paper aims to introduce and test the methodology for selecting the suitable indicators based on the example of two national parks located in the south-east part of Poland. The method composed of the following stages: (1) Selection of spatial units being analyzed; (2) selection of indicators type(s); (3) selection of specific indicators; (4) calculation of indicator set no 1 ; (5) analysis of the correlation between indicators' pairs; (6) selection of a final set of indicators; (7) analysis of effectiveness. The latter stage, refers to the statistical analysis of significance between results obtained dependently on the data sources, a spatial unit of analysis and analyzed regions. The results showed that the categorization composed of ten, mainly composite indicators, can be applied to conclude on different levels of LQ of protected areas. The differences between two analyzed data sources, different spatial units, as well as diverse regions, occurred to be statistically insignificant. Generally, the results of the effectiveness analysis showed that a final categorization of LQ indicators is adequate to conclude on the diverse dimensions of $L Q$ of analyzed protected areas.
\end{abstract}

Keywords: landscape quality; protected areas; national parks; remote sensing; spatial indicators

\section{Introduction}

The formal need for analyses of landscape quality (LQ) was emphasized by the European Landscape Convention [1]. This document underlines the urgent need for defining, assessing and protecting different types of landscape across Europe. One of the steps to do so, is to recognize the quality of landscape as not only landscapes of outstanding beauty should be protected, but also everyday areas, including countryside and urban areas. Although the ELC provides a formal definition of 'landscape' and 'landscape quality objectives', which were intercorporate in law provision on a national level in many countries, no formal definition was proposed to the term 'landscape quality'. In the majority of research, this term is solely connected to the visual layer. As a result, LQ is analyzed based on the analysis of public perception and stakeholder opinion (for example in relation to cultural ecosystem services [2,3]) or by the use of methods combining social and expert point of view (mainly based on the application of GIS methods [4,5]. Taken into account a holistic way in which landscape is nowadays understood, due to the intersection of its many dimensions, a comprehensive evaluation of landscape quality should include a more extensive analysis of the structure and the relationships 
existing between different landscape components [5-7]. In this paper, LQ is understood as the state in which landscape spatial, functional and visual structure is found at a given time. This quality is an effect of superimposing upon a set of environmental components, processes and phenomena that are a direct outcome (e.g., spatial planning and landscape architecture) or a side effect (e.g., agriculture and industry) of human activity. Landscape quality encompasses spatial features (structure of land cover), ecological properties (functioning and diversity of ecosystems), visual features (harmony of forms, shapes, colors etc. and public perceptions of this harmony), as well as cultural value (resources and state of cultural heritage) [6]. LQ depends on the type, variety and density of the landscape elements existing within a specific context and on the level of quality associated with these elements [7].

Understanding of spatial configuration of natural and cultural elements, their connections and their contribution to landscape quality is a difficult task, due to many dimensions to be analyzed. To do so, qualitative and quantitative indicators are applied. They allow the determination of a character of a given area based on numerical values, allowing a large number of data to be reduced to a simple objective form $[8,9]$. These indicators enable a simplification and shortening of the process of evaluation of ecosystems function and structure, as well as being helpful in defining changes, indicating trends and being a long-term tool of monitoring [10]. Taken into account diverse dimensions of landscape quality which can be reflected via the use of indicators, they can be divided into: Structural, ecological, economic, visual, cultural (historical) and social indices [7,11-13]. The analysis of economic and social dimension of LQ requires primarily the use of non-spatial, very specific data which can only be gained through interviews and questionnaires examining the benefits produced by landscape from the point of view of users [6]. They inter alia include: Population density, social structure, availability of services, income values, the willingness to pay to use a certain landscape, the compensation for not using a certain landscape, costs for the conservation of a certain landscape etc. These data can be next analyzed based on the application of GIS techniques, but cannot be directly captured based on multispectral satellite imageries or other products of remote-sensing techniques [5,14]. That is why, dimensions of LQ which can be solely analyzed based on remote sensing data include: Structural, ecological, visual and cultural (Figure 1).

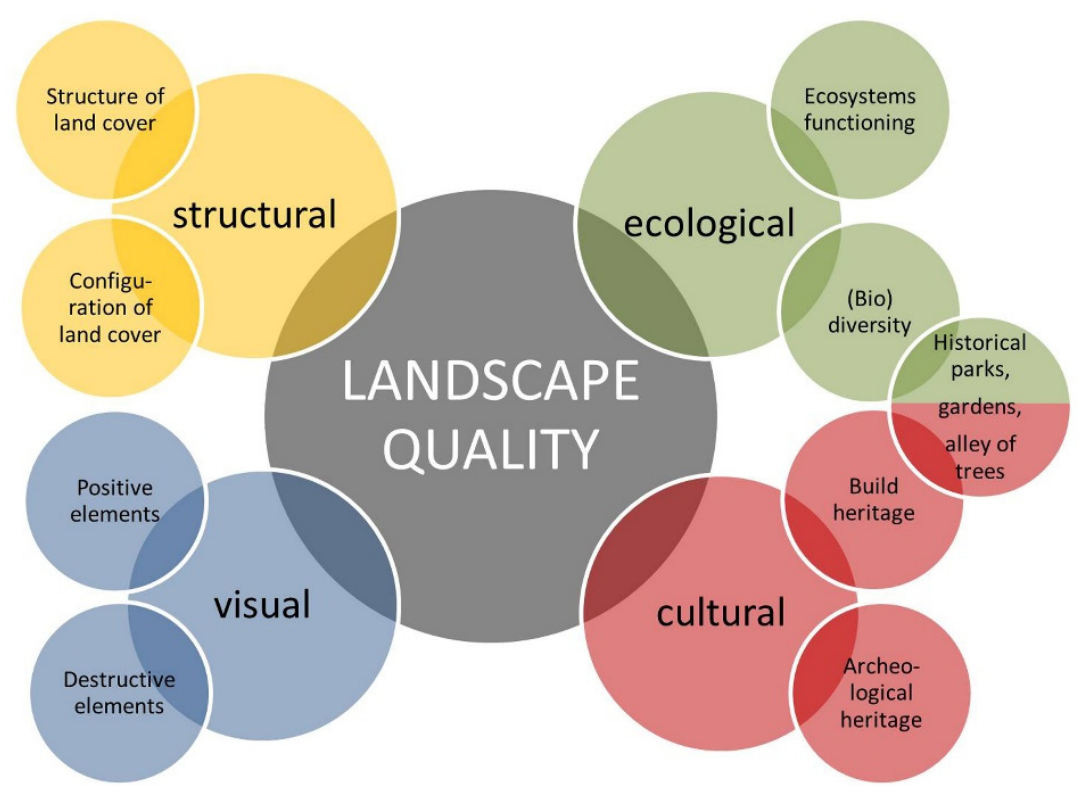

Figure 1. Four dimensions of landscape quality which can be analyzed based on the application of remote sensing data.

Based on remote sensing data, land use structure is the most easily assess the dimension of LQ. It derives from the fact that nowadays we operate with open source and up-to date spatial data which can be used to assess the quality of land use. The most commonly used tools to analyze land use 
structure are so-called landscape metrics, i.e., identifiers based on the structure and configuration of patches of land cover forms in the landscape; they provide data on the area, shape, diversity, adjacency and fragmentation of the patches $[15,16]$. They refer to three spatial dimensions of landscape: Patch, class and landscape as total, which is composed of different patches of different classes of land use. Taken into account diverse landscape characteristics and spatial scales, there are more than 300 different landscape metrics which can be used to assess the structural dimension of the landscape. Most commonly used metrics, however, as quality indicators include number and shape of patches, as well as diversity and fragmentation of the landscape [17].

Indicators based on remote sensing data are widely used to assess ecological the quality of landscape. Generally, three types of indicators can be found in the literature. The first type is geomorphometric indicators, such as elevation a.s.l., angle of repose, exposure and habitat humidity index $[18,19]$. The second indicators, based on spectral variability, refers to the variance plots between bands. In this group different band sets and its variances can be applied as potential indicators. As a result, Reference [20] tested 168 metrics of spectral diversity. Among them, however, Normalized Difference Vegetation Index (NDVI) or its variances (NDVI Sill, NDVI Range, CVNDVI) are the most commonly applied, mainly in biodiversity analysis [21,22]. The third type of landscape metrics, which allow one to quantify, among others, the functioning and stability of ecosystems, their biodiversity and degree of fragmentation $[23,24]$. Besides, to assess ecological the quality of landscape, a vast set of specific authors' s indicators were developed and tested [14,25]. As a result, ecological indicators are the most numerous group of indices composing of indexes based on surface models, hyperspectral satellite imageries and land cover maps.

The review conducted [14], showed that the multitude of cultural quality indicators exists in the literature. They refer to different dimensions of landscape, different characteristics and are of qualitative and quantitative character. In sum, about 200 different indicators dealing with cultural landscape were found in the literature. Most of them, however, cannot be calculated based on remote sensing data. The exceptions are: 'Existence of old habitat trees and fruit trees', 'visibility of disturbing elements and objects' [26], 'degree of unobstructed view '[27], 'viewsheds and landmarks' [28]. Many other indicators must be partially modified to be based on such type of data. For example, indicator called as 'enhancement of urban green' [29] may be spatially reflected by the index which numerically (ha or \%) reflects the changes of the area of green areas in time, or the index called as 'plan that does not spoil natural and historical environment' [30] as the number/percentage of cultural objects and sites affect by a spatial plan based on GIS mapping. Remote sensing, however, is helpful in archaeological research. Based on satellite imagery, we can detect historical structures which are not visible at the ground level and calculate indicators based on their spatial characteristics (i.e., ArcheoGIS).

The most difficult task in LQ research is the assessment of the aesthetic sphere of landscape quality [31]. Many researchers state that the beauty is in the eyes of the beholder, and as a result, our judgement of a particular landscape scene is a result of two factors: Personal characteristics (e.g., cultural and educational background) and particular condition of assessment (weather conditions, sensory quality, our physical and mental state at this moment). The GIS approach is not based on the assumption that the beauty is only in the eyes of the beholder, as there are some landscape features which are perceived in the same way by the majority of observers, and therefore, they can be identified using remote sensing data. Among landscape elements which are positively judged by the majority of the people are blue sky, water and greenery and among these which are judged negatively can be listed destructive human-made objects) $[8,32,33]$. These individual elements, which can be detected by the use of satellite imagery, seen in a view, seem to blend together in time and space into some visual landscape totality [34].

As presented above, the main problem in the assessment of LQ based on remote sensing is not the lack of indicators, but its multitude. To only mention some of the indicators, there are more than 300 landscape metrics which can be used to assess the structural and ecological dimension of LQ, more than 200 metrics of spectral diversity were already tested as a predictor of the ecological state 
of landscape and about 200 different indicators dealing with cultural landscape were found in the literature. Taken into account the above, the paper aims to develop an efficient methodology of LQ analysis taken into account different spatial units, data sources and indicators type to select the best set of LQ indicators. The methodology is presented on the example of two national parks (NP) located in the south-east part of Poland, which are Polesie NP and Roztocze NP. Analyzed regions feature totally different character of the landscape. Polesie comprises old glacial landscape characterized by lowland, and flat, wetland areas. The characteristic elements of this region are lakes usually surrounded by peatbogs and forests. Roztocze region is predominantly covered with complexes of multi-species forest and a multi-stripe field mosaic, with lines of numerous balks overgrown with a variety of weeds and numerous clusters of trees and shrubs [35].

\section{Materials and Methods}

Method of landscape quality analysis of protected areas based on remote sensing data consists of eight stages (Figure 2).

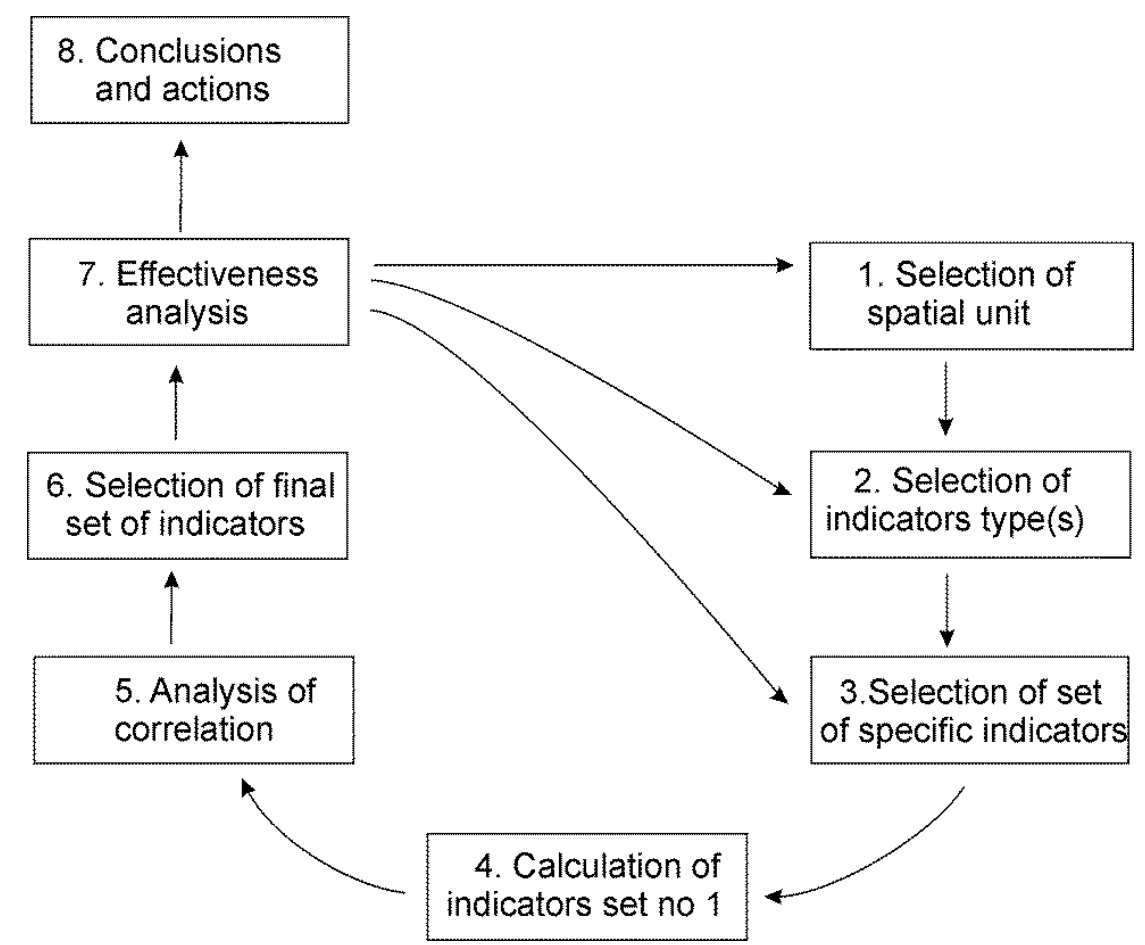

Figure 2. Scheme of landscape quality (LQ) analysis based on the indicators and remote sensing data.

\subsection{Selection of Spatial Units Being Analyzed}

The first stage, which is crucial for the results of further analysis, is the selection of spatial units being analyzed. The link between the effective use of remote sensing data and spatial extent has been reported in relation to ecological conservation by many researchers [36-38]. We can select among natural units, natural-landscape units, administrative borders, ecoregions, landscape scenes and interiors or another kind of areas dependently on the goal of research and availability of data [5,39]. Effective environmental protection, however, requires, on the one hand, the consideration of local-level issues and the elaboration of protected plans for a given protected area (PA). On the other hand, PA cannot be analyzed in isolation from the surrounding, which affects the functioning of the ecosystems inside this area. That is why, it is advisable to analyze PA together with a buffer zone, functional zone or in buffers (circles) around the centroid of an area. Dependently on the protected area size, spatial units being analyzed can range between several (nature reserve) to several hundred (biosphere reserve) hectares. 
Besides, the effective analysis of visual quality requires the application of landscape units, scenes, panoramas or interiors, i.e., areas of the quite similar character of the visual landscape features [5].

To fully test the methodology of LQ analysis, as main spatial units were selected three kinds of areas within the borders of: (1) National park (Polesie NP: $97.62 \mathrm{~km}^{2}$, Roztocze NP: $84.83 \mathrm{~km}{ }^{2}$ ); (2) national park together with: Functional zone (Polesie NP: $316.92 \mathrm{~km}^{2}$ ) or buffer zone (Roztocze NP: $459.11 \mathrm{~km}^{2}$ ); and (3) selected local landscapes (Polesie NP: $21.16 \mathrm{~km}^{2}$; Roztocze NP: $37.01 \mathrm{~km}^{2}$ ). Borders of national parks and buffer zone of Roztocze NP were based on GIS national database of protected areas and constituting formally protected in Polish law forms of environmental protection. These areas were chosen as being basic units of passive and active protected actions undertaken by Pas' managers. Functional zone of Polesie NP was established as a spatial reference scale for elaborating Plan for the protection of Polesie National Park and Natura 2000 areas within the Park (2013) to include external driving forces affected the functionality of socio-ecological ecosystems inside the park. Local landscapes were delineated based on the methodology developed by Sowińska and Chmielewski [40]. These areas are treated as basic units for visual landscape quality analysis as they are relatively homogeneous in terms of several features affecting the landscape physiognomy, including geomorphologic structure, soil types, type of water ecosystem, land relief, and dominant land use structure [5] (Figure 3).

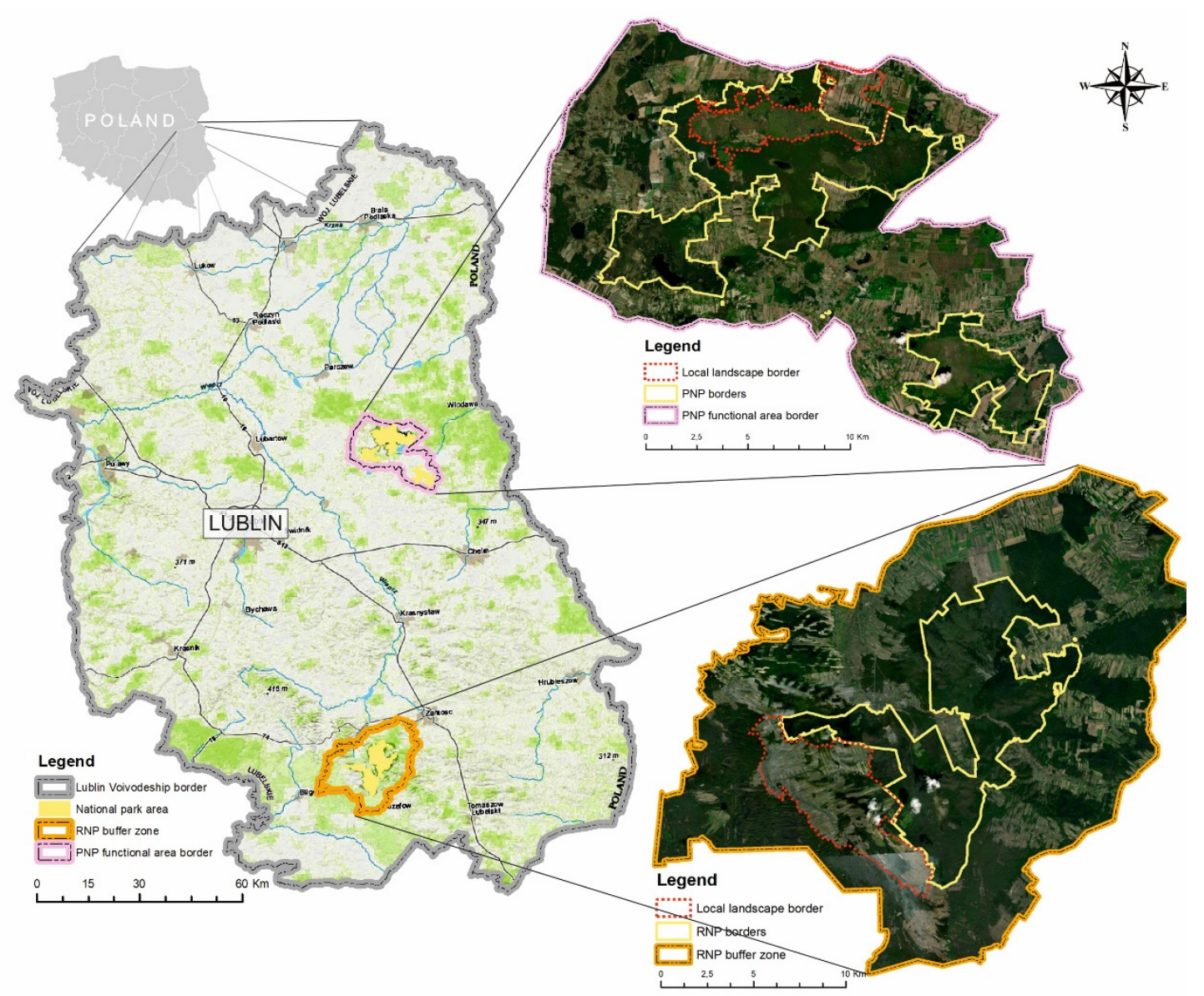

Figure 3. Localization of Polesie and Roztocze regions and types of research areas (Polesie National Park-PNP, Roztocze National Park-RNP).

\subsection{Selection of Indicators' Type(s)}

Effective LQ assessment based on remote sensing data requires the availability of data fulfilling certain criteria which are: (1) High resolution of pixel size; (2) high terrain accuracy; (3) being up-to date; (4) being reliable and based on national standards. Low time-consuming and low labor intensity also require the availability of vector data which contains categorization of land use (LU) or land 
cover (LC) classes being adequate to implement into analysis and management of PA. Besides, data type should be the same, or quite similar for all the analyzed area(s). Such an approach enables the comparison of results among different areas and the formulation of accurate conclusions. Reviews conducted $[5,10,14,41]$ allowed to indicate the main types of LQ indicators in reference to each dimension of quality (Table 1). In the study, the selection of indicators' type was preceded by the analysis of open data sources of two types: (1) European database: Corine Land Cover [42]; (2) National databases: Numerical Terrain Model (NTM grid interval of at least $100 \mathrm{~m}$ ), Database of topographic objects [43], Database of general geographic objects [43], Orthophotomap [44], Forest maps (Forest Data Bank), Map of cultural monuments (Geospatial service of Monuments). With the exception of the last two ones, national databases were obtained from the Polish Main Centre for Geodesic and Cartographic Documentation (GUGIK).

Table 1. Main LQ indicators' types dependently on the analyzed dimension of quality.

\begin{tabular}{cccc}
\hline Structural & Ecological & Cultural & Visual \\
\hline Area and edge metrics & Geomorphometric & Spatial & Social perception \\
Shape metrics & indicators & Architectonical & Presence/absence of \\
Core area metrics & Indicators based on & Historical & given objects \\
Contrast metrics & spectral variability & Social & Compatibility of land \\
Aggregation metrics & Indicators based on & Political & use with landscape type \\
Diversity metrics & landscape structure & Economical & \\
\hline
\end{tabular}

Taken into account the availability of spatial data and its quality the following types of LQ indicators were selected in relation to each dimension of quality, analyzed in this study: (1) Structural (all types of landscape metrics); (2) ecological (indicators based on land cover diversity and presence of ecological barriers); (3) cultural (architectonical, historical); and (4) visual (presence/absence of given land cover types, compatibility of land use with landscape type).

\subsection{Selection of a Set of Specific Indicators}

Specific LQ indicators should be selected based on multi criteria-analysis. One of the methods is the usage of criteria dealing with the criteria of any ideal', 'efficient' or 'smart' indicator (the term differs among authors) $[10,14,45,46]$. In this method, in relation to each specific indicator, a set of questions is raised. In reference to the topic of this paper, the following questions were used: (1) Does an indicator is relevant to the topic under the study (analysis of landscape quality)?; (2) does an indicator can be calculated based on the remote sensing data?; (3) does an indicator is reliable (having a solid scientific basis)?; (4) does an indicator is measurable (easy data collection, easy indicator analysis and update)?; (5) does an indicator is stable (adapt to changing conditions, analyzed long-term changes)? In our research, the above questions were asked in relation to indices pointed by other researchers as a possible tool of LQ analysis-about 200 different indices in sum $[6,10,14,31,47,48]$. Besides, it was assumed that the final categorization of LQ indicators should contain a manageable level of indicators, still adequately reflecting major landscape properties. That is why, structural, ecological and visual spheres were mainly reflected by composite indices. As a result, the categorization applied to analyze the LQ of Polesie and Roztocze NP composed of 11 indicators (Table 2).

\subsection{Calculation of Indicator Set no 1}

Next stage involves the calculation of a set of specific indicators, called as set no 1 in contrast to the final set obtained as a result of the correlation analysis. This stage should be undertaken using GIS software, such as ArcGIS, QGIS, Geomedia, MapInfo professional, SAGA GIS. The software must feature functionalities such as spatial analysis, image analysis tool, terrain analysis and map production. In the research, data management, spatial analysis and visualization were performed based on the ArcGIS 10.5.1 software. 
Table 2. Categorization of landscape quality (LQ) indicators: Set no 1.

\begin{tabular}{|c|c|c|}
\hline Indicator Name & Indicator Abbreviation & Formula \\
\hline \multicolumn{3}{|c|}{ Structural Quality } \\
\hline $\begin{array}{c}\text { Percentage of landscape occupied by a } \\
\text { class of the highest share }\end{array}$ & PLAND & $\frac{\sum_{j=1}^{n} a_{i j}}{T_{A}}$ \\
\hline Mean Patch Area & MPA & $\frac{T A}{N} *(1 / 10000)$ \\
\hline Edge Density & $\mathrm{ED}$ & $\frac{T E}{T A} *(10000)$ \\
\hline Contagion Index & CONTAG & $1+\frac{\sum_{i=1}^{m} \sum_{k=1}^{m}\left[P_{i^{*}} \frac{s_{i k}}{\sum_{k=1}^{m} s_{i k}}\right] *\left[\ln \left(P_{i^{*}} \frac{s_{i k}^{m}}{\sum_{k=1} s_{i k}}\right)\right]}{2 \ln (m)} \mid / 100$ \\
\hline \multicolumn{3}{|c|}{$\begin{array}{l}\text { Data and methods: Based on two data sources: Corine Land Cover (2018) and Database of topographic objects } \\
\text { (BDOT 2012) updated to Orthophotomap (2019); metrics were calculated using Fragstat software [15] } \\
\text { aij- area (m2) of patch I typ j; TA-total area (ha) of landscape; Pi-proportion (\%) of the landscape occupied by } \\
\text { patch type (class) I; gik-number of adjacencies (joins) between pixels of patch types (classes) i and k based on the } \\
\text { double-count method; } \mathbf{m} \text {-number of patch types (classes) present in the landscape, including the landscape } \\
\text { border if present; N-number of patches; TE-total length of borders } \\
\text { Ecological Quality }\end{array}$} \\
\hline $\begin{array}{c}\text { Ecological barriers } \\
\text { Modified Shannon Diversity Index }\end{array}$ & $\begin{array}{l}\text { Ecological Quality } \\
\text { ECOLBAR } \\
\text { MSDI }\end{array}$ & $\left(\mathrm{L}_{\text {road }}+\mathrm{L}_{\text {rail }}\right) /$ Area \\
\hline
\end{tabular}

Data and methods: ECOLBAR and MSDI were based on Corine Land Cover (2018), and Database of topographic objects (BDOT 2012) updated to the newest Orthophotomap (pixel size 0.5m, 2019) and were calculated based on the methodology of Sowińska-Świerkosz [10]

$\mathbf{L}_{\text {rail }}$-length ( $\mathrm{m}$ ) of railways crossing natural, semi-natural and anthropogenic type 1 forms of LC; s-total numbers of LC types; $\mathbf{I}_{\mathbf{1}}$-index which takes into account the ecological significance of LC forms: $\mathbf{I}_{\mathbf{1}}=1$ for natural LC forms $\mathrm{I}_{1}=0.75$ for semi-natural LC forms; $\mathbf{I}_{\mathbf{1}}=0.5$ for type 1 artificial LC forms; $\mathbf{I}_{\mathbf{1}}=0$ for type 2 artificial LC forms

Historical monuments Cultural Quality PROTAP

Historical landscape elements HLE

\section{$\frac{\text { No } \text { monuments }_{\text {a }}}{\text { Area }}$ $\frac{\text { Area }_{\text {histform }}}{\text { Area }}$}

Data and methods: PROTAP and HLE are based on the national register of monuments (Geospatial service of Monuments)

$\mathrm{No}_{\text {monuments }}$-number of cultural monuments; Area—area of spatial unit being analyzed $\left(\mathrm{km}^{2}\right)$; Area histform —area $\left(\mathrm{km}^{2}\right)$ of historical parks, gardens and avenue of trees Visual Quality

Share of positive landscape elements PLE

Form and Color Disharmony Index

FCDHI

Shape Disharmony Index

SDHI

Data and methods: FCDHI and SDHI are based on the methodology of Sowińska-Świerkosz [22] based on two data sources Corine Land Cover (2018) and Database of topographic objects (BDOT 2012) updated to Orthophotomap (pixel size 0.5m, 2019); FRAC was calculated using Fragstat software [15]

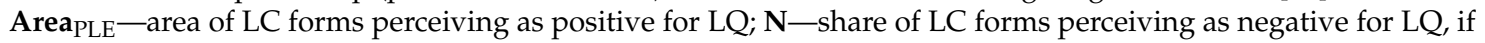
the case of $\mathrm{N}<1$ the $\mathrm{FCDHI}=0 ; \mathrm{S}_{\mathrm{SN}}$-proportion of semi-natural LC forms; $\mathbf{S}_{\mathrm{A}}$-proportion of anthropogenic LC forms; FRAC $_{\mathrm{N}}-$ FRAC index calculated for natural LC forms; FRAC $_{\mathrm{SN}}-$ FRAC index calculated for semi-natural LC forms

All the indicators based on the LC structure were analyzed based on two data sources: Corine Land Cover (2018) and Database of topographic objects (BDOT 2012) updated to Orthophotomap (pixel size $0.5 \mathrm{~m}, 2019$ ). Values of PROTAP and HLE were based on only one data source. In the aim to calculate some of the indicators, data on the state of anthropogenic transformation (ECOLBAR, MSDI, SHDI) and the positive/negative/neutral impact on perceiving visual quality (PLE, FCDI) was ascribed to each of the LC patches in the attribute table. As natural LC forms were treated not-transformed water, peat-bogs and meadows and natural (protected) forests. Semi-natural LC forms include transformed water, peat-bogs and meadows and economy forests. Anthropogenic LC forms type 1 include fields and orchards, and type 2 areas without vegetation, i.e., buildings and roads [10,31]. As LC forms perceive as positive for LQ by the majority of people were treated: Water, natural and semi-natural forms of vegetation; as negative for LQ: Buildings and road infrastructure [32]. 


\subsection{Analysis of Correlation}

Analysis of correlation would give us information on the correlation between analyzed metrics, as well as between other landscape characteristics which may affect the results. Besides, it reduces the number of indices to a manageable level still adequately reflecting major landscape properties, but avoiding doubling-up. In the presented study, analysis of correlations between different indices was based on the results of Spearman rank correlation $(p=0.05)$ for each pair of indices. When the obtained absolute correlation coefficient amounted to 0.8 or more, only one of the two indices was retained.

\subsection{Selection of a Finals Set of Indicators}

The final set of indicators composed of non-correlated indices and constituting a basis for further analysis. In some cases, it is a problematic issue to select which of the two correlated indicators should be selected. The selection involves the careful analysis of a given case study to include more important index(s). Firstly, indicator(s) which is correlated with the highest number of other indices should be removed from the categorization. Then, the priority should be given to composite indices over these of simple form, as they reflect a diverse spectrum of environmental characteristics. Besides, if categorization composed of indices related to different spheres (layers), we cannot remove all the indicators belonging to a given type and as a result ignore a given sphere of landscape quality: Each sphere should be reflected by at least one index; however, more indices are recommended to obtain more approximate picture of the given dimension of landscape quality.

\subsection{Analysis of Effectiveness}

Analysis of indicators effectiveness is crucial to draw a correct conclusion, formulate adequate measures and implement the proper management actions in the field. The negative results of effectiveness analysis may result in need of the modification of all the research, including its first stage which is the selection of landscape unit or further stages, such as the selection of indicators' types or specific indicators (see Figure 2). Analysis of the effectiveness of LQ indicators' categorization should include statistical analysis of differences between the results depending on: Analyzed region, data sources, data quality, unit type, categorization of LC forms, etc. Dependently on the result of the test of normality different statistical tests must be used. The examples are: Student's t-test, in the case of normally distributed data and Manna-Whitney'a in the case of not normally distributed data for two factor groups, and analogously ANOVA test and Kruskala-Wallis test for minimum three factor groups. In the paper, the effectiveness of LQ indicators' categorization was performed based on the comparison of result dependently on: (1) Data sources (CORINE 2018 and BDOT updated to ortophotomap 2019); (2) spatial unit of analysis (national park, national park with a buffer zone, local landscape); (3) analyzed region (Polesie, Roztocze).

\section{Results}

Taken into account two data sources: CORINE land cover and BDOT updated to ortophotomap 2019 and three different spatial scales of analysis in relation to each park six different sets of indicators were calculated-120 indicators' values in total (Table 3).

The results of Spearman rank correlation $(p=0.05)$ for each pair of indices showed that two pairs of indicators are highly correlated (absolute correlation coefficient amounted to 0.8 or more). They are: PROTAP and HLE (0.98) and PROTAP and FCDHI (0.82) (Table 4). Medium correlation features only a few pairs, such as PLAND and CONTAG (0.67), ECOLRBAR and PROTAP (-0.62), MPA and ED (-0.78) and PLE and FCDHI (-0.72), FCDHI and HLE (0.75). As any indicator should be independent meaning non-correlated with other indices, in the final set of LQ indicators was not included index PROTAP showing high correlation with other two indices. As a result, in further analysis categorization composed of ten indicators was analyzed. 
Table 3. Result of calculation of indicators' set no 1.

\begin{tabular}{|c|c|c|c|c|c|c|c|c|c|c|c|c|}
\hline \multirow{3}{*}{$\begin{array}{c}\text { Area/ } \\
\text { Indicator }\end{array}$} & \multicolumn{6}{|c|}{ Polesie NP } & \multicolumn{6}{|c|}{ Roztocze NP } \\
\hline & \multicolumn{2}{|c|}{ NP with Functional Zone } & \multicolumn{2}{|c|}{ NP } & \multicolumn{2}{|c|}{ Local Landscape } & \multicolumn{2}{|c|}{ NP with Buffer Zone } & \multicolumn{2}{|c|}{ NP } & \multicolumn{2}{|c|}{ Local Landscape } \\
\hline & CORINE & BDOT & CORINE & BDOT & CORINE & BDOT & CORINE & BDOT & CORINE & BDOT & CORINE & BDOT \\
\hline PLAND & 27.05 & 36.3 & 11.82 & 34.17 & 58.28 & 60.04 & 35.96 & 34.42 & 47.13 & 50.87 & 58.90 & 75.43 \\
\hline MPA & 90.09 & 5.03 & 34.04 & 7.27 & 21.19 & 4.06 & 158.4 & 18.6 & 56.12 & 16.62 & 51.43 & 1.09 \\
\hline ED & 33.57 & 103.3 & 28.22 & 67.19 & 26.11 & 94.51 & 24.19 & 83.28 & 17.41 & 53.60 & 32.45 & 63.60 \\
\hline CONTAG & 53.90 & 59.46 & 62.02 & 62.44 & 67.66 & 71.99 & 67.75 & 69.71 & 76.29 & 77.18 & 72.16 & 74.44 \\
\hline ECOLBAR & 2.16 & 2.47 & 3.83 & 4.25 & 3.58 & 3.58 & 2.93 & 2.81 & 4.23 & 4.33 & 4.01 & 3.28 \\
\hline MSDI & 0.66 & 0.68 & 0.78 & 0.74 & 0.62 & 0.61 & 0.77 & 0.79 & 0.86 & 0.90 & 0.74 & 0.75 \\
\hline PLE & 0.69 & 0.77 & 0.81 & 0.98 & 0.83 & 0.63 & 0.70 & 0.76 & 0.90 & 0.92 & 0.30 & 0.35 \\
\hline FCDHI & 0.57 & 0.57 & 0.00 & 0.50 & 0.58 & 0.55 & 0.60 & 0.60 & 0.50 & 0.48 & 0.64 & 0.62 \\
\hline SDHI & 0.16 & 0.13 & 0.12 & 0.12 & 0.02 & 0.10 & 0.15 & 0.12 & 0.24 & 0.22 & 0.57 & 0.50 \\
\hline PROTAP & \multicolumn{2}{|c|}{0.03} & \multicolumn{2}{|c|}{0.00} & \multicolumn{2}{|c|}{0.00} & \multicolumn{2}{|c|}{0.09} & \multicolumn{2}{|c|}{0.00} & \multicolumn{2}{|c|}{0.02} \\
\hline HLE & \multicolumn{2}{|c|}{0.001} & \multicolumn{2}{|c|}{0.00} & \multicolumn{2}{|c|}{0.00} & \multicolumn{2}{|c|}{0.002} & \multicolumn{2}{|c|}{0.00} & \multicolumn{2}{|c|}{0.001} \\
\hline
\end{tabular}

Table 4. Spearman rank correlations calculated for pairs of landscape metrics ( $n=12, p<0.05$, values marked with bold are significant correlations at the level of 0.8 or more).

\begin{tabular}{|c|c|c|c|c|c|c|c|c|c|c|c|}
\hline & PLAND & MPA & ED & CONTAG & ECOLBAR & MSDI & PLE & FCDHI & SDHI & PROTAP & HLE \\
\hline PLAND & 1.0 & & & & & & & & & & \\
\hline MPA & -0.46 & 1.0 & & & & & & & & & \\
\hline ED & 0.10 & -0.78 & 1.0 & & & & & & & & \\
\hline CONTAG & 0.67 & -0.17 & -0.17 & 1.0 & & & & & & & \\
\hline ECOLBAR & 0.18 & -0.08 & -0.27 & 0.56 & 1.0 & & & & & & \\
\hline MSDI & -0.21 & 0.21 & -0.31 & 0.51 & 0.40 & 1.0 & & & & & \\
\hline PLE & -0.41 & 0.01 & -0.15 & -0.03 & 0.52 & 0.37 & 1.0 & & & & \\
\hline FCDHI & 0.43 & 0.05 & 0.03 & 0.09 & -0.48 & -0.25 & -0.72 & 1.0 & & & \\
\hline SDHI & 0.26 & 0.21 & -0.25 & 0.48 & 0.14 & 0.42 & -0.32 & 0.30 & 1.0 & & \\
\hline PROTAP & 0.02 & 0.20 & 0.09 & -0.03 & -0.62 & 0.10 & -0.63 & 0.82 & 0.36 & 1.0 & \\
\hline HLE & -0.09 & 0.23 & 0.13 & -0.15 & -0.71 & 0.06 & -0.58 & 0.75 & 0.30 & 0.98 & 1.0 \\
\hline
\end{tabular}


The results showed that the highest share in the LC structure of Polesie NP, independently on the spatial scale considering occupied class 2.3.1 (pastures) according to Corine Land Cover classification (Figure 2A1). According to BDOT classification, the highest share in the LC structure occupied pastures as well (Figure 2B1). Roztocze NP features the highest value of PLAND in the case of coniferous forest according to Corine Land Cover classification (from $35.96 \%$ to $58.90 \%$ dependently on the spatial scale) and according to BDOT classification (from $34.42 \%$ to $75.43 \%$ dependently on the spatial scale). In the case of both NPs, the predominant role of these LC form in shaping ecological structure is clearly at the scale of the local landscape, where PLAND equals to about $60 \%$. Mean Patch Area (MPA) together with Edge Density (ED) is considerably higher for the Polesie NP than Roztocze NP (1.5 to 3 times higher). It may indicate that the degree of fragmentation of LC structure of Polesie NP is higher than in the case of the second park. Polesie is characterized by the dense mosaic of diverse forms of the land cover of irregular shape, whereas in the LC structure of Roztocze predominates the large surface patches. There is also proven by results of CONTAG metric: Lower values typical for Polesie NP shows that patch types are maximally disaggregated and interspersed, wherein CONTAG approaches to 100 show that all patch types are maximally aggregated.

The analysis of the ecological dimension of LQ showed that the density of ecological barriers is quite low and similar in the case of both Parks. Surprisingly, its values are the highest in the case of the spatial scale of NP (ECOBAR = approx. $\left.4 \mathrm{~km} / \mathrm{km}^{2}\right)$, and the lowest in the case of functional/buffer zone $\left(\right.$ ECOBAR $\left.=2-3 \mathrm{~km} / \mathrm{km}^{2}\right)$. It derives from the fact, that as ecological barriers were treated only fragments of paved roads and railways crossing natural and semi-natural land cover forms which predominate in the structure of both Parks. As a result, these finding does not testify on the denser structure of transportation routes inside the park than outside its borders. Is showed that as being of low density, ecological barriers have a low negative effect on the species movement and the continuity of ecological processes inside analyzed parks. High values of the Modified Shannon Diversity Index (MSDI), especially in the case of NP spatial scale $(0.74<$ MSDI $>0.90)$, testify that the landscape of both parks is mostly covered by natural land cover forms which distribution is perfectly even. It is clearly seen analyzing the state of anthropogenic of LC forms of analyzed areas. Natural forms, constituting $39.7 \%$ and semi-natural $34 \%$ of Polesie NP (Figure $4 \mathrm{~A} 2, \mathrm{~B} 2$ ), and respectively, $62.6 \%$ and $5 \%$ of Roztocze NP. The share of anthropogenic LC forms type 2 (areas with no vegetation) is the highest in the case of Roztocze NP buffer zone (3.5\%). In the case of Polesie NP, the share is $2.2 \%$.

The results showed that both areas analyzed at all spatial scales feature high visual landscape quality. Positive landscape elements (PLE), such as water and greenery, occupied about $70 \%$ of functional/buffer zones and between $80 \%$ and almost $100 \%$ of parks' areas. Analyzed areas also feature low share of LC types which are disharmonious in terms of form and/or color, such as dumps, extraction sites and disharmonious forms of settlement (FCDHI equals about 0.50). Low values of SHDI approaching to 0 , with the exception of the local landscape of the Roztocze region, indicate the full harmony of shapes meaning that a landscape presents a mosaic of natural and semi-natural forms of irregular shape.

On the contrary to other dimensions of LQ, analyzed areas showing quite low cultural values of the landscape. It derives from the almost the lack of historical land cover forms and cultural monuments (HLE is approaching to 0), both inside NPs and at the scale of their functional/buffer zones. It derives from the specify of analyses areas, which for many years were excluded from human activities.

Although, some differences among indicators values are clearly seen between two analyzed areas, statistical comparison of the total values obtained for all scales showed no statistical significance (Table 5). The results showed that applied indicators' categorization occurred to be effective to reflect diverse landscape characteristics by dealing with diverse LC forms in the same manner. It was achieved by the application of indicators based on the state of anthropogenic transformation and the positive/negative/neutral impact on perceived visual quality. As a result, lakes of Polesie NP have the same quality value as forests of Roztocze region. 


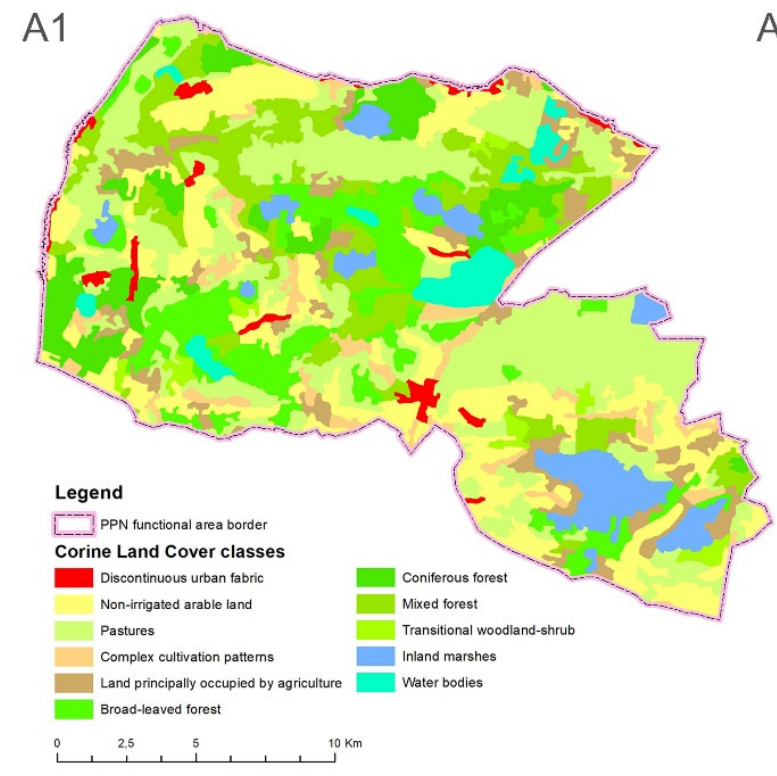

A2
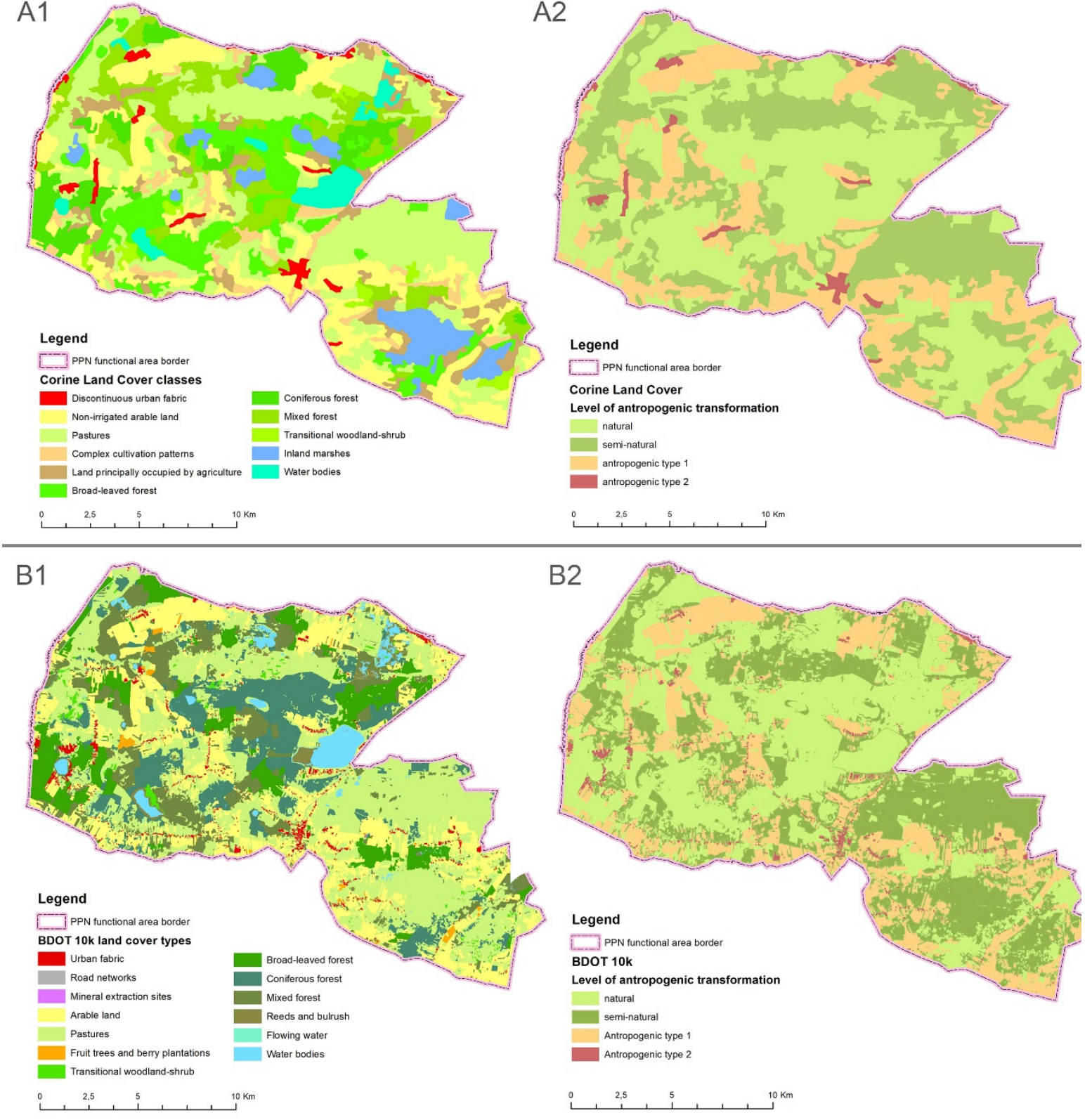

Figure 4. Example (Polesie functional zone) of the use of two data sources: CORINE land cover classification (A1) and based on this data map illustrating the level of anthropogenic transformation of LC forms (A2); BDOT land cover classification (B1) and based on this data map illustrating the level of anthropogenic transformation of LC forms (B2).

Table 5. Results of Manna-Whitney'a test for factor groups (levels Polesie NP and Roztocze NP, $\mathrm{p}<0.05)$.

\begin{tabular}{cccc}
\hline \multirow{2}{*}{ Type of Data } & Both type of Data & CORINE & BDOT \\
\cline { 2 - 4 } & $\begin{array}{c}\mathbf{n}=\mathbf{6 0} \\
\text { median }\end{array}$ & $\begin{array}{c}\mathbf{n}=\mathbf{3 0} \\
\text { median }\end{array}$ & $\begin{array}{c}\mathbf{n}=\mathbf{3 0} \\
\text { median }\end{array}$ \\
\hline Polesie NP & 1.53 & 1.49 & 1.73 \\
Roztocze NP & 1.04 & 1.91 & 1.01 \\
U value & 1768.50 & 412.00 & 436.00 \\
p value & 0.869 & 0.574 & 0.836 \\
\hline
\end{tabular}


The result showed that the difference between two data sources is not statistically significant, also in the case of all the analyzed spatial units (Table 6). It is quite surprising, taken into account the fact that terrain accuracy of CORINE is much lower than of BDOT. In the research, it is reflected by the fact that the number of patches (NP) was 10 to 30 times higher for BDOT than for CORINE, dependently on the special scale and the region. Besides, a number of LC types (PR) was 15 to $20 \%$ higher for the national database. As a result, clear differences are seen in relation to mean patch area (MPA) and edge density (ED). However, the cumulative impact of all the ten indicators showed the lack of statistical significance between the two data sources. It derives from the fact, that mainly composite indicators were used, i.e., indicators formed by other indices compiled into a single index.

Table 6. Results of Manna-Whitney'a test for factor groups (levels CORINE and BDOT, $\mathrm{p}<0.05$ ).

\begin{tabular}{|c|c|c|c|c|}
\hline \multirow{2}{*}{ Type of Data } & $\begin{array}{c}\text { All Type of } \\
\text { Spatial Units }\end{array}$ & $\begin{array}{c}\text { NP with } \\
\text { Functional Zone }\end{array}$ & NP & Local Landscape \\
\hline & $\begin{array}{l}\mathrm{N}=54 \\
\text { median }\end{array}$ & $\begin{array}{l}\mathrm{N}=18 \\
\text { median }\end{array}$ & $\begin{array}{l}\mathrm{N}=18 \\
\text { median }\end{array}$ & $\begin{array}{l}\mathrm{N}=18 \\
\text { median }\end{array}$ \\
\hline CORINE & 3.71 & 2.55 & 4.03 & 3.80 \\
\hline BDOT & 3.05 & 2.64 & 4.29 & 2.19 \\
\hline U value & 1433 & 161.50 & 149.50 & 159.00 \\
\hline $\mathrm{p}$ value & 0.878 & 0.988 & 0.696 & 0.938 \\
\hline
\end{tabular}

The Kruskala-Wallis test showed that the differences between the results obtained for different spatial units are also statistically insignificant $(n=120 ; \alpha=0.05 ;$ Fcrit $=3.087 ; F 2,117=0.245 ; p=0.782)$. It indicates that in relation to the test areas, the effectiveness of LQ indicators was not affected by the spatial extent considering. All of the spatial scales, including functional/buffer zone, national park and local landscape can be used as a reference unit of LQ analysis in relation to protected areas.

\section{Discussion}

\subsection{Landscape Quality of Test Areas}

The major problem with LQ assessment derives from the fact that we cannot state that the quality of a given spatial unit equals to one or 15 . While interpreting values of $L Q$, we cannot understand them as an ordinary numerical value, i.e., the higher the values of indexes, the higher the quality. What we can do is to elaborate on the ranking of the spatial units in terms of their quality and indicate units which quality, positively or negatively, differs from the background. The pilot study showed that the applied methodology was adequate to do so, in the case of two analyzed PA, as the rank of quality measures was similar in the case of Polesie and Roztocze NP.

The research results generally showed that both test areas are featuring high values in relation to structural and ecological LQ. These findings are consistent with other researchers based on the application of landscape indicators to analyze landscape quality of the Roztocze nad Polesie NP showing that low degree of anthropogenic fragmentation and stable ecological state of this area [10,41,49]. Within the area of Polesie NP from the beginning of XX century, significant changes have taken place in the water relations, in the land use structure and in the character of landscape physiognomy. In spite of changes that took place, the area has natural richness, clean air, large water and forest supplies, the good physical structure of the settlements and diversity in the ways of living [50]. The similar analysis conducted in relation to different types of Polish protected areas also showed that the landscape quality of national parks is substantially higher than of other forms of nature protection [51]. Generally, the high effectiveness of landscape metrics to reflect the structural and ecological quality of protected areas was proven by many studies, both to conclude on the general level of quality [52], as well as on selected layers of ecological state, such as naturalness or wetland loss and fragmentation [53]. 
The application of indicators also revealed high visual landscape quality of both analyzing national parks. Such findings in relation to Polesie and Roztocze protected areas were also proven by the results of studies analyzing social perceptions and stakeholder opinions on perceived values [35], linking social and expert valorization [5], as well as use physiognomic structure analysis [49,54]. It indicates that objective indices, as proposed in this study, can be used to indirectly reflect intangible values of the landscape which is beauty or harmony. It can be done by done as in visual quality assessment; the most crucial is the impact of a given set of attributes affecting the overall scenic beauty [32]. Such approach was adopted in this study in the structure of PLE, FCDHI, and SHDI indicators: Vegetation and water were treated as of positive impact for visual values, and negative human-made elements, such as roads dumps and dilapidated buildings, as negative [55-57].

The application of indicators revealed low quality cultural values. To discuss this finding, it should be emphasized, that in literature the cultural dimension of landscape quality is linking to three general types of objects: Built heritage (listed monuments), forms of greenery designed by man and intangible values (e.g., identity, perception, transformation) [6,14]. Indicator HLE used in this study deals with only one type of cultural dimension: Forms of greenery designed by man, such as parks, gardens and avenue of trees. Indicators PROTAP based on the existence of built heritage was excluded, due to its high correlation with other indices. Its values, however, are also approaching to 0 indicating low cultural values as analyzed areas are mainly covered by natural and semi-natural land cover forms (also including buffer/functional zones). The categorization lacks the consideration of the third dimension of cultural values: Intangible features which are high importance, while perceiving protected areas $[3,27,58]$. Intangible values, however, cannot be capture based on remote-sensing data. That is why, to fully examine the issue of the selection of LQ indicators next to spatial data should be used non-spectral ones referring to the indication of places of high values to the general public. The concept of cultural ecosystem services may be helpful here, to categorize, indicate, analyze and spatially reflect nonmaterial benefits people obtain from ecosystems $[59,60]$.

\subsection{Methodology of LQ Analysis Based on the Application of Remote-Sensing}

The main result of the paper dealing with the fact that no statistically significant differences were found between different analyzed factor groups. This finding needs further discussion on its impact on the effectiveness of the proposed methodology.

Generally, the research showed that data, both on national and European/Pan-European level, could be used to calculate LQ indicators. It is quite surprising, taking into account the fact that terrain accuracy of CORINE is much lower than of BDOT. As a result, CORINE does not include small-scale and dispersed patches of LC, such as settlement or plantings [61,62], which should be more clearly defined [63]. In the research, it is reflected by the fact that the values of NP, PR and MPA differ significantly between two data sources. The cumulative impact of all the ten indicators, however, showed the lack of statistical significance between the two data sources. It derives from the fact, that mainly composite indicators were used, i.e., indicators formed by other indices compiled into a single index. Such indices are useful when single indicators cannot adequately capture multi-dimensional concepts, such as fragmentation or biodiversity [11]. Of course, more test areas, including protected and non-protected areas, should be analyzed to fully examine this issue. CORINE database, however, has two advantages standing it out from other data: The uniform representation of LC forms for all Europe allowing the comparison in space, and different time data series allowing the comparison in time. In other studies, dealing with the issue of LQ assessment, the impact of data source was not analyzed, and the selection of spatial data was based on the availability and quality of data. In some studies, authors' classifications of LC forms and the minimal mapping unit of 0.1ha was used [35], wherein in others the spatial scale of landscape scene [64] or scale of heritage landscapes [65] was used to reflect LQ.

The paper also takes part in the discussion on the method of the selection of an adequate unit of analysis $[36-38,66]$ which influences the results of further research stages. The pilot study showed 
no statistically significant dependence between three analyzed spatial units: Functional/buffer zone, national park and local landscape. Taken into account, however, different characters of each dimension of LQ better solution is to calculate indicators for different spatial extents, than only in relation to one spatial scale. For example, that effective analysis of visual quality should be undertaken in relation to easily visible in the field areas, possessing visually detected borders, such as landscape panoramas, scenes or interiors [67-69]. Such approach is especially advisable in the aim to formulate guidelines on the design of landscape which preserve visual quality, highlight the unique features of a given region and build a sense of the place identity [53]. As a result, small scale analysis is more useful than a broad scale one. On the other hand, structural and ecological LQ is affected by the configuration of LC patches of surrounding areas [70]. Thus, homogenous ecological units seem to be the most adequate from the point of view of protection policies and planning [39]. Therefore, the situation is reversed: Regional scale analysis is more satisfactory than local ones. Such approach of adopting different spatial scales in LQ assessment was inter alia adopted by the division into regional and local scale [6], and regional and landscape unit scale [5]. Besides, it should be remembered that sometimes analysis undertaken only within the borders of a given protected area are incorrect, as expert-based landscape designations may not accurately or adequately reflect public views on landscapes and additional public input to inform decision-making may be needed. These can be done by using a GIS-based survey to generate maps of areas/objects of outstanding values according to general public perception and then evaluate the degree of concordance between results obtained and protected landscapes recommended for designation by experts [4]. As a result, existing borders of Pas may be adjusted to reflect public views or public opinion may be incorporated in the designation process of new Pas.

\section{Conclusions}

The test of the new methodology for selecting the suitable LQ indicators based on the example of two national parks showed that:

1. The categorization, composed of ten, mainly composite indicators, is adequate to conclude on different levels of LQ.

2. Both test areas featuring high values in relation to structural, ecological and visual LQ, and low, while analyzing the cultural dimension.

3. Applied indicators' categorization occurred to be effective to reflect diverse landscape characteristics by dealing with diverse LC forms in the same manner. It was achieved by the application of indicators based on the state of anthropogenic transformation and the positive/negative impact on perceived visual quality.

4. The research showed that data, both on national and European/Pan-European level, could be used to calculate LQ indicators. More test areas should be analyzed to fully examine this issue.

5. Differences between different spatial scales occurred to be statistically insignificant, indicating that the effectiveness of indices is not affected by the spatial extent. Taken into account, however, different characters of each dimension of LQ better solution is to calculate indicators for different spatial extents, than only in relation to one spatial scale.

6. To fully examine the issue of the selection of LQ indicators the comparison between protected areas of the different regime, as well as between protected and non-protected areas together with the comparison of result with non-spectral data sources, especially these referring to the intangible values, is needed. To do so, presented methodology based on the application of remote sensing data constituting the first, fundamental step.

Author Contributions: The following statements should be used Conceptualization, B.S.-Ś. methodology, B.S.-Ś.; software, M.M.-Ś., B.S.-Ś.; validation, B.S.-Ś.; M.M.-Ś.; formal analysis, B.S.-Ś.; investigation, B.S.-Ś.; M.M.-Ś.; resources, B.S.-Ś.; M.M.-Ś.; data curation, B.S.-Ś.; M.M.-Ś.; writing—original draft preparation, B.S.Ś.S.; writing—review and editing, B.S.ŚS.; visualization, M.M.-Ś.; supervision, B.S.-Ś.; project administration, B.S.-Ś., M.M.-S.; funding acquisition, M.M.-S., All authors have read and agree to the published version of the manuscript. 
Funding: The research was founded by the Ministry of Science and Higher Education (Poland) for the dissemination of science (766/P-DUN/2019).

Conflicts of Interest: The authors declare no conflict of interest.

\section{References}

1. Council of Europe 2007. The European Landscape Convention Text. Available online: http://conventions.coe. int/treaty/en/Treaties/Html/176.htm (accessed on 12 December 2019).

2. Battisti, L.; Corsini, F.; Gusmerotti, N.M.; Larcher, F. Management and Perception of Metropolitan Natura 2000 Sites: A Case Study of La Mandria Park (Turin, Italy). Sustainability 2019, 11, 6169. [CrossRef]

3. Canedoli, C.; Bullock, C.; Collier, M.J.; Joyce, D.; Padoa-Schioppa, E. Public Participatory Mapping of Cultural Ecosystem Services: Citizen Perception and Park Management in the Parco Nord of Milan (Italy). Sustainability 2017, 9, 891. [CrossRef]

4. Conrad, E.; Fazey, J.; Christie, M.; Galdies, C. Choosing landscapes for protection: Comparing expert and public views in Gozo, Malta. Landsc. Urban Plan. 2019, 191, 103621. [CrossRef]

5. Sowińska-Świerkosz, B.; Chmielewski, T.J. A new approach of the identification of Landscape Quality Objectives (LQOs) as a set of indicators. J. Environ. Manag. 2016, 184, 596-608. [CrossRef]

6. Cassatella, C.; Peano, A. Landscape Indicators. In Assessing and Monitoring Landscape Quality; Cassatella, C., Peano, A., Eds.; Springer: Berlin/Heidelberg, Germany, 2011.

7. Vizzari, M. Spatial modelling of potential landscape quality. Appl. Geogr. 2011, 31, 108-118. [CrossRef]

8. Swetnam, R.D.; Tweed, F.S. A tale of two landscapes: Transferring landscape quality metrics from Wales to Iceland. Land Use Policy 2018, 76. [CrossRef]

9. Hersperger, A.M.; Mueller, G.; Knöpfel, M.; Kienast, F. Evaluating outcomes in planning: Indicators and reference values for Swiss landscapes. Ecol. Indic. 2017, 77, 96-104. [CrossRef]

10. Sowińska-Świerkosz, B. The application of surrogate measures of ecological quality assessment: The introduction of the Indicator of Ecological Landscape Quality (IELQ). Ecol. Indic. 2017, 73, 224-234. [CrossRef]

11. OECD. The OECD-JRC Handbook on Practices for Developing Composite Indicators. In Paper Presented at the OECD Committee on Statistics; OECD: Paris, France, 2004.

12. Santé, I.; Fernández-Ríos, A.; Tubío, J.M.; García-Fernández, F.; Farkova, E.; Miranda, D. The Landscape Inventory of Galicia (NW Spain): GIS-web and public participation for landscape planning. Land Res. 2018, 44, 212-240. [CrossRef]

13. Asur, F. An evaluation of visual landscape quality of coastal settlements: A case study of coastal areas in the Van Lake Basin (Turkey). Appl. Ecol. Environ. Res. 2019, 17, 1849-1864. [CrossRef]

14. Sowińska-Świerkosz, B. Review of cultural heritage indicators: Types, categorisation schemes and their usefulness in landscape quality assessment. Ecol. Indic. 2017, 81, 526-542. [CrossRef]

15. McGarigal, K.; Cushman, S.A.; Ene, E. FRAGSTATS v3: Spatial Pattern Analysis Program for Categorical and Continuous Maps, Computer Software Pro-Gram Produced by the Authors at the University of Massachusetts; University of Massachusetts: Amherst, MA, USA, 2002.

16. Otieno, F.; Olumuyiwa, O.; Ochieng, G. Land cover change assessment of vaal harts irrigation scheme using multi-temporal satellite data. Arch. Environ. Prot. 2013, 39, 59-70. [CrossRef]

17. Van Eetvelde, V.; Antrop, M. A stepwise multi-scaled landscape typology and for trans-regional integration, applied on the federal state of Belgium. Landsc. Urban Plan. 2009, 9, 160-170. [CrossRef]

18. Chundi, C.; Shengjun, W.; Douglas, M.C.; Maohua, M.; Juanjuan, Z.; Mingquan, L.; Xiaoxiao, T. Effects of local and landscape factors on exotic vegetation in the riparian zone of a regulated river: Implications for reservoir conservation. Landsc. Urban Plan. 2017, 157, 45-55.

19. Mello Coelho, L.F.; Ribeiro, M.C.; Pereira, R.A.S. Water availability determines the richness and density of fig trees within Brazilian semideciduous forest landscapes. Acta Oecol. 2014, 57, 109-116. [CrossRef]

20. Warren, S.D.; Alt, M.; Olson, K.D.; Irl, S.D.H.; Steinbauer, M.J.; Jentsch, A. The relationship between the spectral diversity of satellite imagery, habitat heterogeneity, and plant species richness. Ecol. Inform. 2014, 24, 160-168. [CrossRef] 
21. Mapfumo, R.B.; Murwira, A.; Masocha, M.; Andriani, R. The relationship between satellite-derived indices and species diversity across African savanna ecosystems. Int. J. Appl. Earth Obs. Geoinf. 2016, 52, 306-317. [CrossRef]

22. Narantsetseg, A.; Kang, S.; Lkhamsuren, B.E.; Jang, K.; Ko, D.W. Assessment of biotic and abiotic factors controlling herbaceous biodiversity in Mongolian steppes. Ecol. Inform. 2015, 29, 221-229. [CrossRef]

23. Hill, M.J.; Heino, J.; White, J.C.; Ryves, D.B.; Wood, P.J. Environmental factors are primary determinants of different facets of pond macroinvertebrate alpha and beta diversity in a human-modified landscape. Biol. Conserv. 2019, 237, 348-357. [CrossRef]

24. Qua, Y.; Sun, G.; Luo, C.; Zeng, X.; Zhang, H.; Murray, N.J.; Xu, N. Identifying restoration priorities for wetlands based on historical distributions of biodiversity features and restoration suitability. J. Environ. Manag. 2019, 231, 1222-1231. [CrossRef]

25. Gottero, E. Identifying vulnerable farmland: An index to capture high urbanisation risk areas. Ecol. Indic. 2019, 98, 61-67. [CrossRef]

26. Szücs, L.; Anders, U.; Bürger-Arndt, R. Assessment and illustration of cultural ecosystem services at the local scale -A retrospective trend analysis. Ecol. Indic. 2015, 50, 120-134. [CrossRef]

27. Loomis, D.K.; Paterson, S.K. Human dimensions indicators of coastal ecosystem services: A hierarchical perspective. Ecol. Indic. 2014, 44, 63-68. [CrossRef]

28. Peña, L.; Casado-Arzuaga, I.; Onaindia, M. Mapping recreation supply and demand using an ecological and a social evaluation approach. Ecosyst. Serv. 2015, 13, 108-118. [CrossRef]

29. Bruni, D. Landscape quality and sustainability indicators. Agric. Agric. Sci. Procedia 2016, 8, 698-705. [CrossRef]

30. Erdogan, N.; Tosun, C. Environmental performance of tourism accommodations in the protected areas: Case of Goreme Historical National Park. Int. J. Hosp. Manag. 2009, 28, 406-414. [CrossRef]

31. Sowińska-Świerkosz, B. Index of Landscape Disharmony (ILDH) as a new tool combining the aesthetic and ecological approach to landscape assessment. Ecol. Indic. 2016, 70, 166-180. [CrossRef]

32. Sowińska-Świerkosza, B.; Soszyński, D. The index of the Prognosis Rural Landscape Preferences (IPRLP) as a tool of generalizing peoples' preferences on rural landscape. J. Environ. Manag. 2019, 248, 109272. [CrossRef]

33. Yao, Y.; Zhu, X.; Xu, Y.; Yang, H.; Wu, X.; Li, Y.; Zhang, Y. Assessing the visual quality of green landscaping in rural residential areas: The case of Changzhou, China. Environ. Monit. Assess. 2012, 184, 951-967. [CrossRef]

34. Clay, G.R.; Smidt, R.K. Assessing the validity and reliability of descriptor variables used in scenic highway analysis. Landsc. Urban Plan. 2004, 66, 239-255. [CrossRef]

35. Sowińska-Świerkosz, B.; Chmielewski, T.J. Comparative Assessment of Public Opinion on the Landscape Quality of Two Biosphere Reserves in Europe. Environ. Manag. 2014, 54, 531-556. [CrossRef] [PubMed]

36. Andelman, S.J.; Willig, M.R. Alternative configurations of conservation reserves for Paraguayan bats: Considerations of spatial scale. Conserv. Biol. 2002, 16, 1352-1363. [CrossRef]

37. Huber, P.R.; Greco, S.E.; Thorne, J.H. Spatial scale effects on conservation network design: Tradeoffs and omissions in regional versus local scale planning. Land. Ecol. 2010, 25, 683-695. [CrossRef]

38. Rouget, M. Measuring conservation value at fine and broad scales: Implications for a diverse and fragmented region, the Agulhas Plain. Biol. Conserv. 2003, 112, 217-232. [CrossRef]

39. Jalilian, M.A.; Shayesteh, K.; Danehkar, A.; Salmanmahiny, A. A new ecosystem-based land classification of Iran for conservation goals. Environ. Monit. Assess. 2020, 192, 182. [CrossRef]

40. Sowińska, B.; Chmielewski, T.J. Local landscapes: Delineation, diagnosis, design guidelines. Probl. Landsc. Ecol. 2012, 33, 277-290. (In Polish)

41. Sowińska-Świerkosz, B.; Soszyński, D. Landscape structure versus the effectiveness of nature conservation: Roztocze region case study (Poland). Ecol. Indic. 2014, 43, 143-153. [CrossRef]

42. Corine Land Cover (CLC 2018). Copernicus. Available online: https://land.copernicus.eu/pan-european/ corine-land-cover/clc2018 (accessed on 7 December 2019).

43. Baza Danych Obiektów Topograficznych. Available online: http://www.gugik.gov.pl/strona-glowna (accessed on 10 December 2019).

44. Ortofotomapa. Available online: http://www.gugik.gov.pl/pzgik/zamow-dane/ortofotomapa (accessed on 10 December 2019). 
45. Lindenmayer, D.; Pierson, J.; Barton, P.; Beger, M.; Branquinho, C.; Calhoun, A.; Caro, T.; Greig, H.; Gross, J.; Heino, J.; et al. A new framework for selecting environmental surrogates. Sci. Total. Environ. 2015, 538, 1029-1038. [CrossRef]

46. Repetti, A.; Desthieux, G. A relational indicator set model for urban land-use planning and management: Methodological approach and application in two case studies. Landsc. Urban Plan. 2006, 77, 196-215. [CrossRef]

47. Hermes, J.; Albert, C.; von Haaren, C. Assessing the aesthetic quality of landscapes in Germany. Ecosyst. Serv. 2018, 31, 296-307. [CrossRef]

48. Uuemaa, E.; Antrop, M.; Roosaare, J.; Marja, R.; Mander, U. Landscape Metrics and Indices: An Overview of Their Use in Landscape Research. Living Rev. Landsc. Res. 2009, 3, 1-28. [CrossRef]

49. Chmielewski, T.J.; Kułak, A.; Michalik-Śnieżek, M.; Lorens, B. Physiognomic structure of agro-forestry landscapes: Method of evaluation and guidelines for design, on the example of the West Polesie Biosphere Reserve. Int. Agrophys. 2016, 30, 415-429. [CrossRef]

50. Chmielewski, T.J.; Chmielewski, S.; Kułak, A.; Michalik-Śnieżek, M.; Maślanko, W. Landscapes of the West Polesie. In Regional Identity and Its Transformation over the Last Half Century; University of Life Sciences in Lublin: Lublin, Poland, 2015.

51. Kubacka, M. Evaluation of the ecological efficiency of landscape protection in areas of different protection status. A case study from Poland. Landsc. Res. 2019, 44, 628-641. [CrossRef]

52. Amaral, Y.T.; Santos, E.M.D.; Ribeiro, M.C.; Barreto, L. Landscape structural analysis of the Lençóis Maranhenses national park: Implications for conservation. J. Nat. Conserv. 2019, 51, 125725. [CrossRef]

53. Chunyan, L.; Chunying, R.; Zongming, W.; Bai, Z.; Weidong, M.; Hao, Y.; Yibin, G.; Mingyue, L. Monitoring and Assessment of Wetland Loss and Fragmentation in the Cross-Boundary Protected Area: A Case Study of Wusuli River Basin. Remote Sens. 2019, 11, 2581. [CrossRef]

54. Chmielewski, T.J. Landscape systems. In Structure, Funcioning, Planning; Polish Scientific Publishing (PWN): Warszawa, Poland, 2012. (In Polish)

55. Arriaza, M.; Canas-Ortega, J.F.; Canas-Madueno, J.A.; Ruiz-Aviles, P. Assessing the visual quality of rural landscapes. Landsc. Urban Plan. 2004, 69, 115-125. [CrossRef]

56. Bulut, Z.; Yilmaz, H. Determination of landscape beauties through visual quality assessment method: A case study for Kemaliye. Environ. Monit. Assess. 2008, 141, 121-129. [CrossRef]

57. Howley, P. Landscape aesthetics: Assessing the general publics' preferences towards rural landscapes. Ecol. Econ. 2011, 72, 161-169. [CrossRef]

58. Nahuelhual, L.; Carmona, A.; Laterra, P.; Barrena, J.; Aguayo, M. A mapping approach to assess intangible cultural ecosystem services: The case of agriculture heritage in Southern Chile. Ecol. Indic. 2014, 40, 90-101. [CrossRef]

59. Boyd, J.; Banzhaf, S. What Are Ecosystem Services? The Need for Standardized Environmental Accounting Units. Ecol. Econ. 2007, 63, 616-626. [CrossRef]

60. Haines-Young, R. Report of Results of a Survey to Assess the Use of CICES, 2016. Support to EEA tasks under the EU MAES Process. Negotiated procedure No EEA/NSS/16/002. Millennium Ecosystem Assessment (MEA). Ecosystems and Human Well-being: Current State and Trends. Volume 1. Findings of the Conditions and Trends. In Working Group of the Millennium Ecosystems Assessment; Island Press: Washington, DC, USA, 2005; pp. 1-917.

61. Cole, B.; Smith, G.; Balzter, H. Acceleration and fragmentation of CORINE land cover changes in the United Kingdom from 2006-2012 detected by Copernicus IMAGE2012 satellite data. Intern. J. Appl. Earth Obs. Geoinf. 2018, 73, 107-122. [CrossRef]

62. Di Sabatino, A.; Coscieme, L.; Vignini, P.; Cicolani, B. Scale and ecological dependence of ecosystem services evaluation: Spatial extension and economic value of freshwater ecosystems in Italy. Ecol. Indic. 2013, 32, 259-263. [CrossRef]

63. Diaz-Pacheco, J.; Gutiérrez, J. Exploring the limitations of CORINE land cover for monitoring urban land-use dynamics in metropolitan areas. J. Land Use Sci. 2014, 9, 243-259. [CrossRef]

64. Loupa Ramos, I. Exploratory landscape scenarios in the formulation of landscape quality objectives. Futures 2010, 42, 682-692. [CrossRef] 
65. Van Eetvelde, V.; Antrop, M. From Landscape Atlas to Flemish Heritage Landscapes. Using landscape inventories to formulate landscape quality objectives in a participative process. Landscapes of Everyday Life. In Crossed Perspectives on Research and Action, Proceedings of the PDD International Conference, Perpignan, France and Gerona, Spain, 16-18 March 2011; Terrason, D., Ed.; UNISCAPE: Zoetermeer, The Netherlands; p. 2011.

66. Simensen, T.; Holvorsen, R.; Erikstad, L. Methods for landscape characterisation and mapping: A systematic review. Land Use Policy 2018, 75, 557-569. [CrossRef]

67. Kause, C. Our visual landscape: Managing the landscape under special consideration of visual aspects. Landsc. Urban Plan. 2001, 54, 239-254.

68. Nijhuis, S.; van Lammeren, R.; van der Hoeven, F. Exploring the Visual Landscape. In Advances in Physiognomic Landscape Research in the Netherlands; IOS Press: Amsterdam, The Netherlands, 2011.

69. Nijnik, M.; Zahvoyska, L.; Nijnik, A.; Ode, A. Public evaluation of landscape content and change: Several examples from Europe. Land Use Policy 2008, 26, 77-86. [CrossRef]

70. White, M.A.; Cornett, M.W.; Wolter, P.T. Two scales are better than one: Monitoring multiple-use northern temperate forests. For. Ecol. Manag. 2017, 384, 44-53. [CrossRef]

(C) 2020 by the authors. Licensee MDPI, Basel, Switzerland. This article is an open access article distributed under the terms and conditions of the Creative Commons Attribution (CC BY) license (http://creativecommons.org/licenses/by/4.0/). 